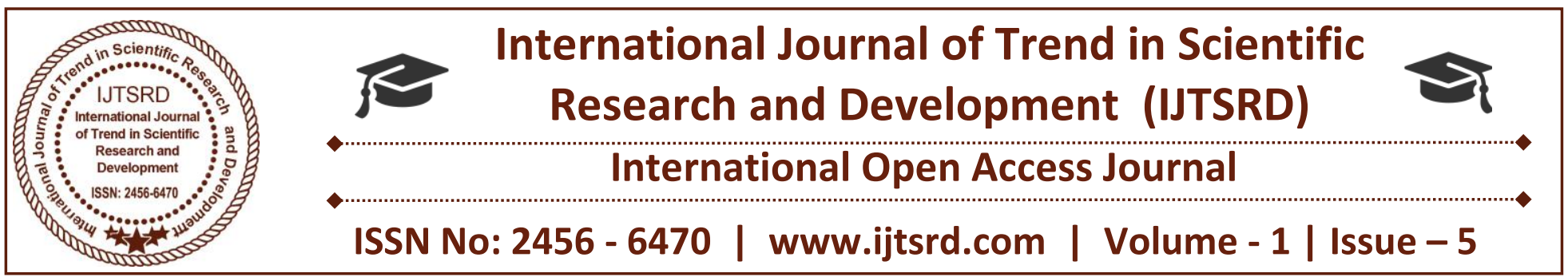

\title{
Tax Saving Instruments of Income Tax in India: A Study on Tax Assessee in Trichy City
}

\author{
K.Saravanan \\ Research Scholar, Bishop Heber College \\ (Autonomous), Tiruchirappalli, \\ Tamil Nadu, South India
}

\author{
Dr.K.MuthuLakshmi \\ Associate Professor of Commerce, Bishop Heber \\ College (Autonomous), Tiruchirappalli, \\ Tamil Nadu, South India
}

\section{ABSTRACT}

To study the planning of individual income tax and tax saving instruments of individual income tax. By doing so they can plan in advance about their Tax savings instrument. Tax planning is an essential part of our financial planning. Efficient tax planning enables us to reduce our tax liability to the minimum. This is done by legitimately taking advantage of all tax exemptions, deductions under chapter VIA, rebates and allowances while ensuring that your investments are in line with their long-term goals. The purpose of the study is to find out the most suitable and popular tax saving instrument used to save tax and also to examine the amount saved by using that instrument. Over all findings reveals that the most adopted tax saving instrument is Provident Fund, which got the first rank in this study and the second most adopted tax saving instrument is Life Insurance policy.

Keywords: Tax, Income Tax, Tax saving Instruments, Tax Saving Planning, Tax Avoidance

\section{Tax}

Let us begin by understanding the meaning of tax. Tax is a fee charged by a government on a product, income or activity. There are two types of taxes direct taxes and indirect taxes (See Chart below this paragraph). If tax is levied directly on the income or wealth of a person, then it is a direct tax e.g. incometax. If tax is levied on the price of a good or service, then it is called an indirect tax e.g. excise duty. In the case of indirect taxes, the person paying the tax passes on the incidence to another person.

\section{Tax Law in India}

Income-tax is the most significant direct tax. In this material, we would be introducing the students to the Income-tax law in India.

Income-tax Act, 1961: The levy of income-tax in India is governed by the Income-tax Act, 1961. In this book we shall briefly refer to this as the Act. This Act came into force on 1st April 1962. The Act contains 298 sections and XIV schedules. These undergo change every year with additions and deletions brought about by the annual Finance Act passed by Parliament. In pursuance of the power given by the Income-tax Act, 1961 rules have been framed to facilitate proper administration of the Income-tax Act, 1961.

Income-tax Rules: The administration of direct taxes is looked after by the Central Board of Direct Taxes (CBDT). The CBDT is empowered to make rules for carrying out the purposes of the Act. For the proper administration of the Income-tax Act, 1961, the CBDT frames rules from time to time. These rules are collectively called Income-tax Rules, 1962. It is important to keep in mind that along with the Incometax Act, 1961, these rules should also be studied. 


\section{Levy of Income-Tax}

Income-tax is a tax levied on the total income of the previous year of every person. A person includes an individual, Hindu Undivided Family (HUF), Association of Persons (AOP), Body of Individuals (BOI), a firm, a company etc.

\section{Assessee}

Assessee [Section 2(7)]: Assessee means a person by whom any tax or any other sum of money is payable under this Income-tax Act, 1961. It includes every person in respect of whom any proceeding has been taken for the assessment of his income or assessment of fringe benefits. Sometimes, a person becomes assessable in respect of the income of some other persons. In such a case also, he may be considered as an assessee. This term also includes every person who is deemed to be an assessee or an assessee in default under any provision of this Act.

\section{Tax Planning}

Tax Planning is an exercise undertaken to minimize tax liability through the best use of all available allowances, deductions, exclusions, exemptions, etc., to reduce income.

Tax planning can be defined as an arrangement of one's financial and business affairs by taking legitimately in full benefit of all deductions, exemptions, allowances and rebates so that tax liability reduces to minimum. In other words, all arrangements by which the tax is saved by ways and means which comply with the legal obligations and requirements and are not colorable devices or tactics to meet the letters of law but the spirit behind these, would constitute tax planning.

In brief tax planning may be defined as an arrangement of one's financial affairs in such a way that without violating in any way the legal provisions of an Act, full advantages are taken of all exemptions, deductions, rebates and reliefs permitted under the Income Tax-act, so that the burden of the taxation on an assessee, as far as possible be the least.

Actually the exemptions, deductions, rebates and reliefs have been provided by the legislature to achieve certain social and economic goals. For example section 80IB of the Income Tax Act, 1961 provides deduction from gross total income in respect of profits from newly established industrial undertakings in industrially backward State or industrially backward district as may be notified in this behalf. The object of the tax concession is clear, i.e., economic development of industrially backward district or State. Section 80C provides deduction from gross total income, if an individual or H.U.F. saves the amount and invests or deposits it in the prescribed schemes. The deduction has been provided to encourage savings and investments for economic development of the country. Thus, if a person takes .the advantages of the aforesaid deductions, he not only reduces his tax liability but also helps in achieving the objective of the legislature, which is lawful, social and ethical. Thus, tax planning is an act within the four corners of the Act and it is not a colourable device to avoid the tax liability

\section{Tax Evasion}

It refers to a situation where a person try to reduce his tax liability by deliberately suppressing the income or by inflating the expenditure showing the income lower than the actual income and resorting to various types of deliberate manipulations. An assessee guilty of tax evasion is punishable under the relevant law. Tax evasion may involve stating an untrue statement knowingly, submitting misleading documents, suppression of facts, not maintaining proper accounts of income earned (if required under the law) omission of material facts in assessments. An assessee, who dishonestly claims the benefit under the statute by making false statements, would be guilty of tax evasion.

\section{Tax avoidance}

The line of demarcation between tax planning and tax avoidance is very thin and blurred. There could be element of mollified motive involved in the tax avoidance also. Any planning which, through done strictly according to legal requirements defeats the basic intention of the legislature behind the statute could be termed as instance of tax avoidance. It is usually done by adjusting the affair in such a manner the there is no infringement of taxation laws and $b$ taking full advantage of the loopholes there in so as to attract the least incidence of tax. Earlier tax avoidance was considered completely legitimate, but at present it may be illegitimate in certain situations only.

\section{Tax management}

Tax planning is a broader term which requires management of affairs in such a way that results in the reduction in minimisation of tax liability. Tax planning is not possible without tax management. Tax 
International Journal of Trend in Scientific Research and Development (IJTSRD) ISSN: 2456-6470

management is an internal part of the tax planning. It takes necessary precautions to comply with the legal formalities to avail the tax exemption/ deductions, rebates or relief as are contempt's in the scheme of tax planning. Tax management plays a vital role in calming allowance, deductions and tax exemptions by complying with the required conditions. For example, Where an assessee follows mercantile system of accounting, the claim of expenses should be made, subject to the provisions of section $43 \mathrm{~B}$, on accrual bases, if the assessee fails to make such a claim, such expenses can not be deducted in subsequent years. Similarly, the specified deductions under section 80IA, section 80JJA, etc,. Tax management also protects an assessee against penalty and prosecution by discharging tax obligations in time. Thus, the study of tax planning is incomplete without tax management. Tax planning without the study of tax management is like knowing the medicine without knowing how to administer it.

\section{DIFFERENCE BETWEEN TAX PLANNING' AND TAX MANAGEMENT'}

Tax planning primarily aims at adopting an arrangement so as to bring about the least incidence of tax under the four corners of law. On the other hand, tax management comprises a wider field like compliance with the statutory provisions of law, prospective planning to ease the financial constraints if any, that would arise when discharging the commitments through payment of tax, keeping close watch and monitoring the statutory requirements of other laws, claiming the due reliefs arising on account of double taxation avoidance agreements or claiming unilateral relief, etc. Thus, while tax planning is the pivot which enables the drawing up of the different incentives and keeps the incidence of tax law, the tax management is the revolving wheel, which translates the policy in terms of results. The difference between tax planning and tax management are stated as under:

1. Tax planning is a wider-term. It includes tax management. Tax management is the first step towards tax planning.

2. The primary aim of tax planning is minimizing incidence of tax, whereas main aim of tax management is compliance with legal formalities.

3. Tax planning is not essential for every assessee, while tax management is essential for every person, otherwise he may be liable for penal interest, penalty and prosecution. For example, a person may not be reducing his tax liability by claiming any exemption, deduction, relief, etc. in computing his total income but if he is liable to pay advance tax or responsible for deduction of tax at source, etc. he has to comply with all legal formalities.

4. Tax planning is a guide in decision making while tax management -is a regular feature of an undertaking.

5. In tax planning exemptions, deductions and reliefs are claimed while in tax management the conditions are complied with to claim the exemptions, deductions and reliefs.

6. In tax planning alternative economic activities are studied and an activity with the least incidence of tax is selected whereas tax management includes maintenance of accounts in prescribed form, getting books audited, filing the required forms and returns, payment of taxes, etc.

7. Tax planning essentially looks at future benefits arising out of present actions. Tax management relates to past, present and future. In respect of appeals, revision, rectification of mistakes, etc. it deals with the past. Maintenance of records, self-

8. Assessment, filing the return and other documents, keeping pace with the changes, etc. are present activities. Follow-up plans, etc. are in the future.

\section{Review of Literature}

VD Lall1982, in his paper tried to find out the economic implication of direct taxes on individual and business. His study exposed that both average rate of tax and marginal rate of tax have bearing on mind set of the tax paper so there is need to give professional look to the present tax system of the country.

Peter et al ,2001 investigated that taxation in its various form affect the ability and willingness of a individual to work, save and invest but the effect gets vary according to the base of tax, rate of tax and level of tax burden.

Ankita 2009, in her study propounded that a small attempt to rationalize the personal income tax structure can bring benefitsto the govt as well as to the people in the form of( i)increase in the number of assesses (ii) more compliance to the tax laws (iii) high rate of GDP and (iv) better well being of the individuals.

Nirmala dorasamy,2011 provided an overview of personal income tax administration reforms as a 
International Journal of Trend in Scientific Research and Development (IJTSRD) ISSN: 2456-6470

mechanism to enhance collection of revenue on the one hand and availability of more pool of fund for welfare of the public on the other. The author found that a comprehensive tax policy encourage the individual to compliance tax law otherwise they adopt unfair mean to lessen their tax burden.

\section{Objective of the Study}

1. To study the planning of individual income tax.

2. To study the saving instrument of individual income tax.

\section{RESEARCH METHODOLOGY}

The study of the research design is descriptive in nature because it throws light on relationship between assessee income and income level on tax saving amount. Research methodology is a way to systematically solve the problem. The sampling technique adopted was Stratified Random Sampling Technique. The population for this study consists of the assessee in the Trichy City. The choice of respondents included in the survey is chosen at random and 100 assessee were taken up as the sample. Primary data was collected through personal interviews and use of questionnaires to gather accurate information. Secondary data was obtained from available sources such as text books, journals, on-line published articles, information from the local newspapers and internet search engines among others.

\section{TAX SAVING INSTRUMENTS}

Income Tax Deductions for FY 2016-17 (AY 201718), Tax Deduction limits under few Sections of the Income Tax Act. The important sections and new proposals with respect to Income Tax Deductions FY 2016-17. This list can help you in planning your taxes.

\section{Section 80C}

The maximum tax exemption limit under Section 80C has been retained as Rs 1.5 Lakh only. The various investment avenues or expenses that can be claimed as tax deductions under section $80 \mathrm{c}$ are as below:

$>$ PPF (Public Provident Fund)

$>$ EPF (Employees' Provident Fund)

$>$ Five year Bank or Post office Tax saving Deposits

$>$ NSC (National Savings Certificates)

$>$ ELSS Mutual Funds (Equity Linked Saving Schemes)

$>$ Kid's Tuition Fees
$>$ SCSS (Post office Senior Citizen Savings Scheme)

$>$ Principal repayment of Home Loan

$>$ NPS (National Pension System)

$>$ Life Insurance Premium

$>$ Sukanya Samriddhi Account Deposit Scheme

\section{Section 80CCC}

Contribution to annuity plan of LIC (Life Insurance Corporation of India) or any other Life Insurance Company for receiving pension from the fund is considered for tax benefit. The maximum allowable Tax deduction under this section is Rs 1.5 Lakh.

\section{Section 80CCD}

Employee can contribute to Government notified Pension Schemes (like National Pension Scheme NPS). The contributions can be upto $10 \%$ of the salary Gross Income Further, additional deduction of upto Rs 50,000 benefit u/s 80CCD (1b).

To claim this deduction, the employee has to contribute to Govt recognized Pension schemes like NPS. The $10 \%$ of salary limit is applicable for salaried individuals and Gross income is applicable for non-salaried. The definition of Salary is only 'Dearness Allowance.' If your employer also contributes to Pension Scheme, the whole contribution amount (10\% of salary) can be claimed as tax deduction under Section 80CCD (2).

Kindly note that the Total Deduction under section 80C, 80CCC and 80CCD (1) together cannot exceed Rs $1,50,000$ for the financial year 2016-17. The additional tax deduction of Rs 50,000 u/s 80CCD (1b) is over and above this Rs 1.5 Lakh limit.

\section{Section 80D}

Deduction u/s $80 \mathrm{D}$ on health insurance premium is Rs 25,000 . For Senior Citizens it is Rs 30,000. For very senior citizen above the age of 80 years who are not eligible to take health insurance, deduction is allowed for Rs 30,000 toward medical expenditure.

Preventive health checkup (Medical checkups) expenses to the extent of Rs 5,000/- per family can be claimed as tax deductions. Remember, this is not over and above the individual limits as explained above. (Family includes: Self, spouse, dependent children and parents). 


\section{Section 80DD}

You can claim up to Rs 75,000 for spending on medical treatments of your dependents (spouse, parents, kids or siblings) who have $40 \%$ disability. The tax deduction limit of upto Rs 1.25 lakh in case of severe disability can be availed.

\section{Section 80DDB}

An individual (less than 60 years of age) can claim upto Rs 40,000 for the treatment of specified critical ailments. This can also be claimed on behalf of the dependents. The tax deduction limit under this section for Senior Citizens is Rs 60,000 and for very Senior Citizens (above 80 years) the limit is Rs 80,000 . To claim Tax deductions under Section 80DDB, it is mandatory for an individual to obtain 'Doctor Certificate' or 'Prescription' from a specialist working in a Govt or Private

hospital.

\section{Section 80E}

If you take any loan for higher studies, tax deduction can be claimed under Section $80 \mathrm{E}$ for interest that you pay towards your Education Loan. This loan should have been taken for higher education for you, your spouse or your children or for a student for whom you are a legal guardian. Principal Repayment on educational loan cannot be claimed as tax deduction. There is no limit on the amount of interest you can claim as deduction under section $80 \mathrm{E}$. The deduction is available for a maximum of 8 years or till the interest is paid, whichever is earlier.

\section{Section 80EE}

Additional deduction for interest on housing loan borrowed for acquisition of self -occupied house property by an individual (over and above the deduction of Rs.2 lakshs under section 24). First time Home Buyers can claim an additional Tax deduction of up to Rs 50,000 on home loan interest payments u/s $80 \mathrm{EE}$. The below criteria has to be met for claiming tax deduction under section 80EE.

$>$ The home loan should have been sanctioned in FY 2016-17.

$>$ Loan amount should be less than Rs 35 Lakh.

$>$ The value of the house should not be more than Rs 50 Lakh \&

$>$ The home buyer should not have any other existing residential house in his name.

\section{Section 24 (B)}

Interest payable on House loans borrowed can be claimed as deduction under Section 24B for up to Rs 2 lakh in case of a self-occupied house. If your property is a let-out one then the entire interest amount can be claimed as tax deduction. Interest related to years of completion of construction can be fully claimed irrespective of completion date.

\section{Section 80G}

Contributions made to certain relief funds and charitable institutions can be claimed as a deduction under Section $80 \mathrm{G}$ of the Income Tax Act. This deduction can only be claimed when the contribution has been made via cheque or draft or in cash. But deduction is not allowed for donations made in cash exceeding Rs 10,000. In-kind contributions such as food material, clothes, medicines etc do not qualify for deduction under section $80 \mathrm{G}$.

\section{Section 80GG}

The Tax Deduction amount under $80 \mathrm{GG}$ has been increased from Rs 24,000 per annum to Rs 60,000 per annum. Least of the following allowable as deduction:

$>25 \%$ of total income.

$>$ Rent paid- $10 \%$ of total income.

$>$ Rs.5000

\section{Section 87A Rebate}

If you are earning below Rs 5 lakh, you can save an additional Rs 3,000 in taxes. Tax rebate under Section 87A has been raised from Rs 2,000 to Rs 5,000 for FY 2016-17 (AY 2017-18). In case if your tax liability is less than Rs 5,000 for FY 2016-17, the rebate $\mathrm{u} / \mathrm{s} 87 \mathrm{~A}$ will be restricted up to income tax liability only.

\section{Section 80 TTA}

Deduction from gross total income of an individual or HUF, up to a maximum of Rs. 10,000/-, in respect of interest on deposits in savings account with a bank, co-operative society or post office can be claimed under this section. Section 80TTA deduction is not available on interest income from fixed deposits.

\section{Section 80U}

This is similar to Section 80DD. Deduction in case of a person with disability any person, who is certified by the medical authority to be a person with disability. Permissible deduction Rs.75,000 in case of a person with disability. Rs. 125,000 in case of a person with severe disability ( $80 \%$ or more disability). 


\section{ANALYSIS AND INTERPRETATION}

Figure 1: Gender of the respondents

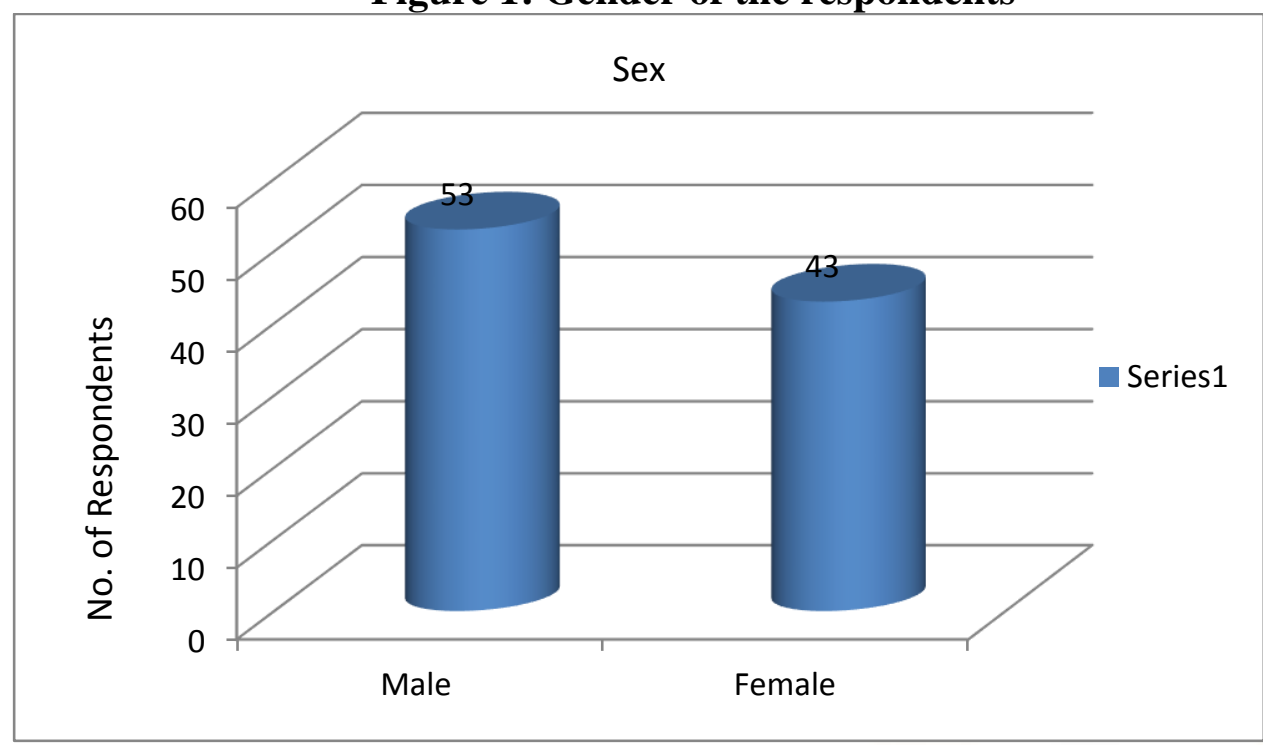

The total numbers of respondents are 100 in which there are 53 male \& 47 female respondents. The percentage of male \& female respondents is $53 \% \& 47 \%$ respectively.

Figure 2: Age of the Respondents

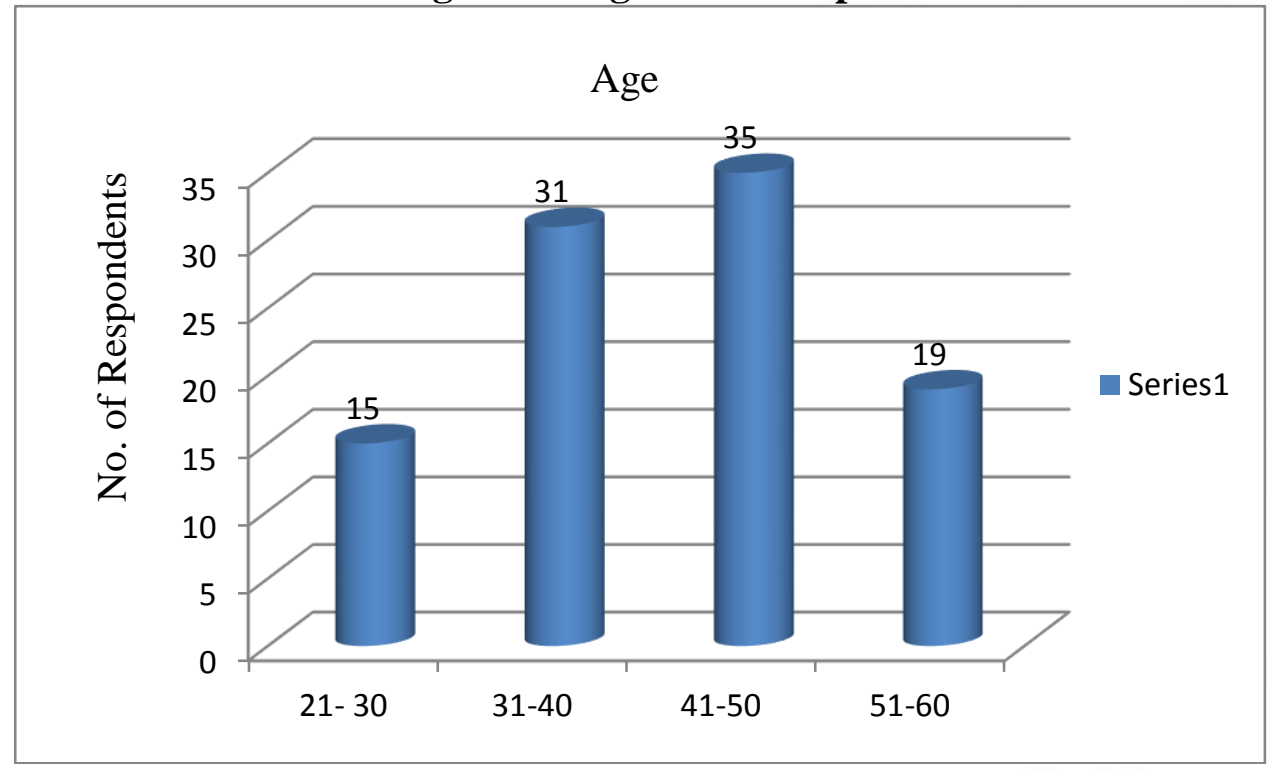

The age of the respondents are classified in to five groups, In which 15 respondents (15\%) are from the age group of 21-30, 31 respondents (31\%) are from the age group of 31-40, 35 respondents (35\%) are from the age group of 41-50, 19 respondents (19\%) are from the age group of 51-60 
Figure 3: Occupation of the Respondents

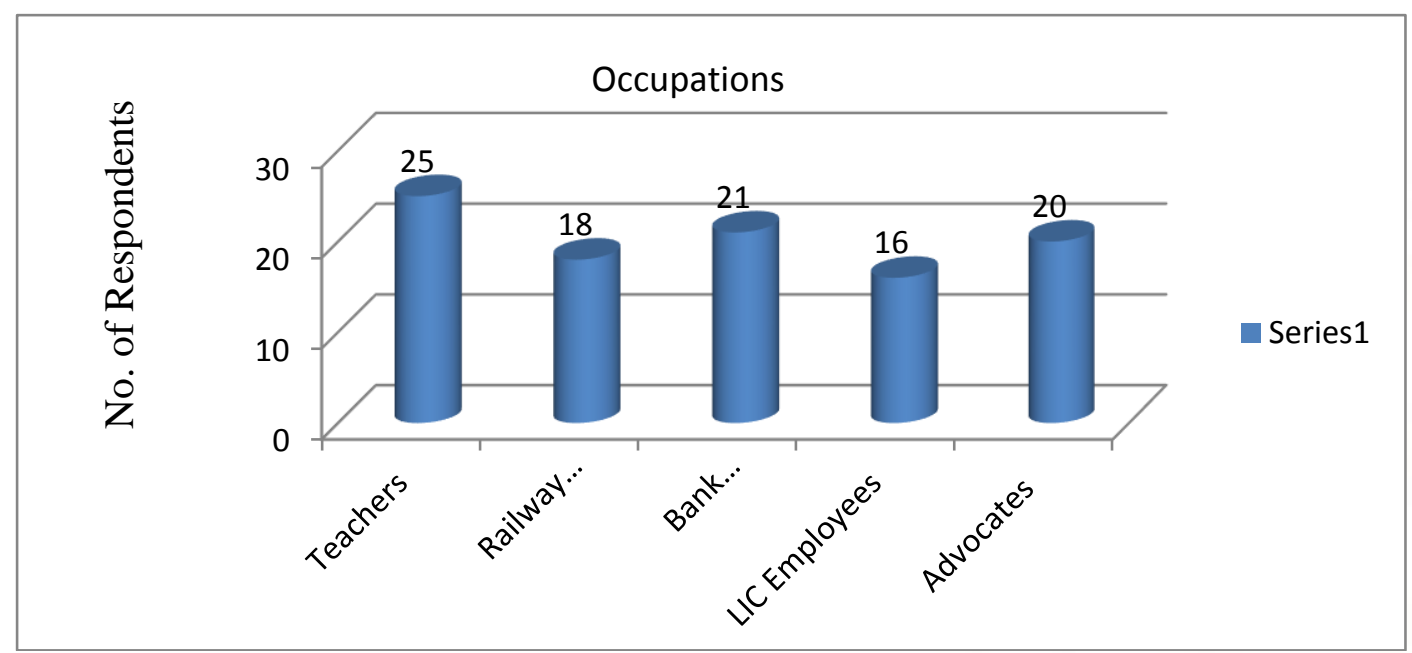

The total respondents are further divided in to five classes, which includes 25 teachers(25\%), 18 railway employees (18\%), 21 bank employees (21\%), LIC employees, 20 Advocates (20\%).

Figure 4: Respondents of the Income

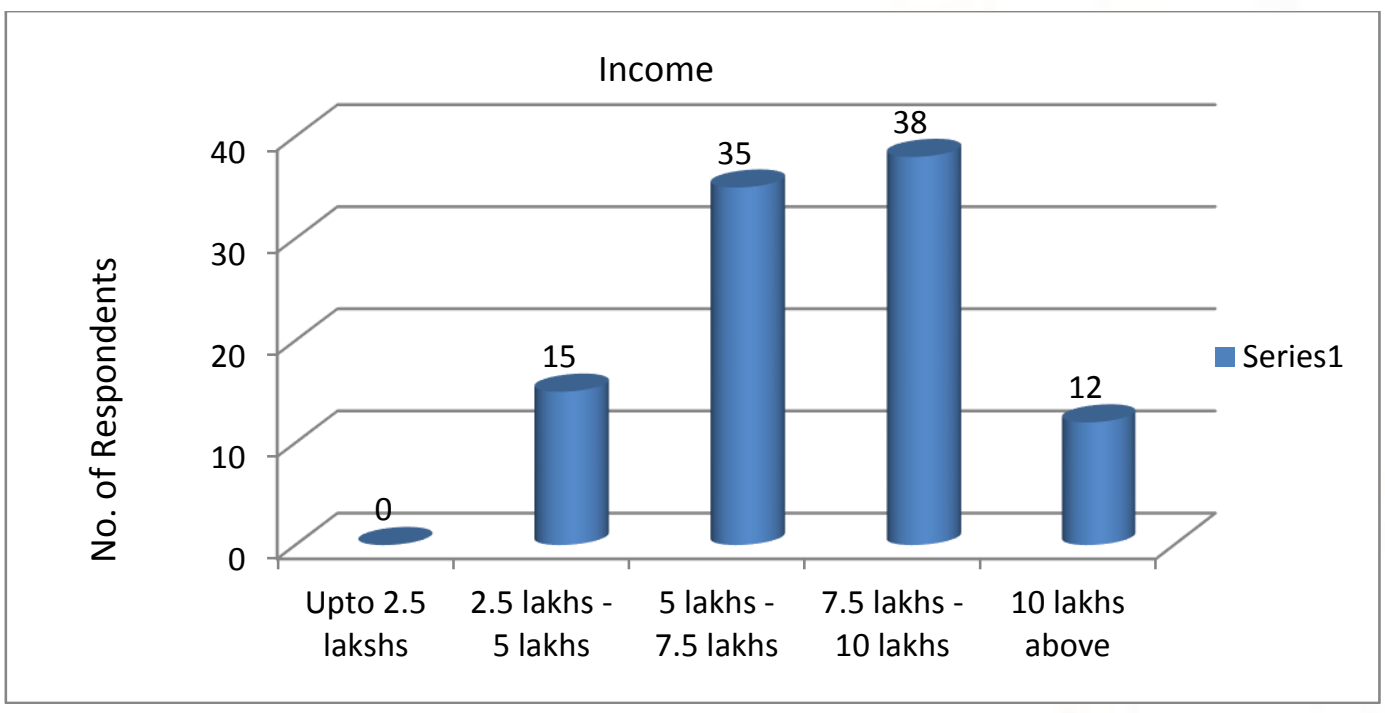

The respondents below the income 2.5 lakhs are $0(0 \%)$, between the incomes of 2.5 to 5 lakhs are $15(15 \%)$, between the incomes of 5 to 7.5 lakhs are 35 (35\%), between the incomes of 7.5 to 10 lakhs are 38 (38\%) and the income more than 10 lakhs are $12(12 \%)$. 
Figure 5: Amount invest in Tax Saving Investment

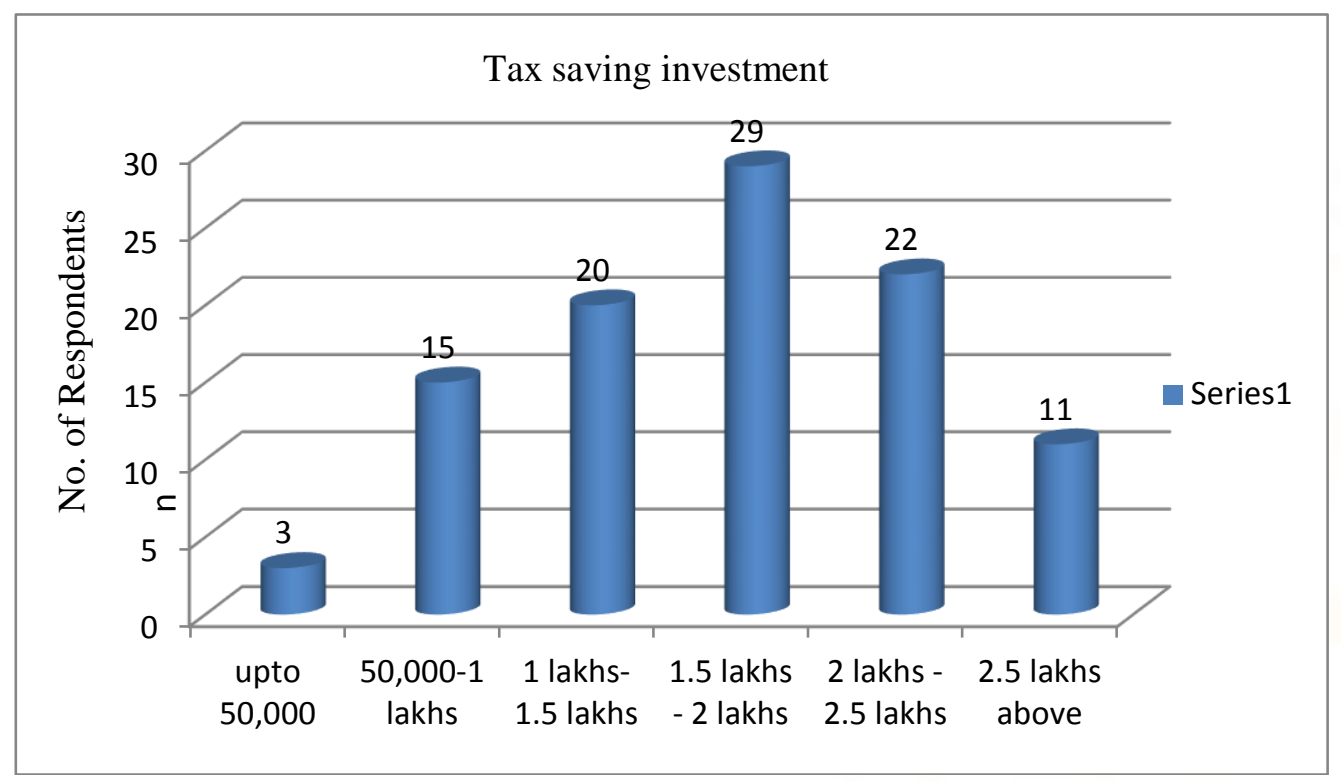

There are 3 respondents (3\%), who save less then Rs. 50,000, 15 respondents (15\%), who save between Rs. 50,000 to 1 lakhs, 20 respondents (20\%), who save between Rs. 1lakhs to 1.5 lakhs, 29 respondents (29\%), who save between Rs. 1.5 lakhs to 2 lakhs, 22 respondents (22\%), who save between Rs. 2 lakhs to 2.5 lakhs, and 11 respondents (11\%), who save above Rs. 2.5 lakhs.

Table 1: Preferred Tax Saving Instruments

\begin{tabular}{|l|l|l|l|l|l|l|l|}
\hline $\begin{array}{l}\text { Instruments } \\
\text { saving }\end{array}$ & $\begin{array}{l}\text { Strong } \\
(5)\end{array}$ & $\begin{array}{l}\text { High } \\
(4)\end{array}$ & $\begin{array}{l}\text { Neutral } \\
(3)\end{array}$ & $\begin{array}{l}\text { Low } \\
(2)\end{array}$ & $\begin{array}{l}\text { Very Low } \\
(1)\end{array}$ & Mean & Rank \\
\hline PPF/EPF & 85 & 9 & 2 & 4 & 0 & 4.75 & I \\
\hline LIC & 66 & 19 & 7 & 6 & 2 & 4.41 & II \\
\hline $\begin{array}{l}\text { HL Interest/ } \\
\text { Principal }\end{array}$ & 60 & 19 & 7 & 9 & 5 & 4.20 & III \\
\hline Tuition Fees & 62 & 14 & 14 & 0 & 10 & 4.18 & IV \\
\hline Fixed Deposit & 55 & 19 & 10 & 7 & 9 & 4.04 & V \\
\hline NPS & 50 & 17 & 10 & 14 & 9 & 3.85 & VI \\
\hline NSC & 41 & 20 & 13 & 14 & 12 & 3.64 & VII \\
\hline HI & 37 & 19 & 20 & 12 & 12 & 3.57 & VIII \\
\hline Donation & 37 & 19 & 18 & 9 & 17 & 3.50 & IX \\
\hline ELSS & 32 & 15 & 16 & 22 & 15 & 3.27 & X \\
\hline
\end{tabular}

Source- based on primary data

According to these responses, rank is given to various tax saving instruments. The respondents preferred Provident fund as the best tax saving instrument and ranked as One. Life insurance is the $\mathrm{II}^{\mathrm{nd}}$ highest ranked tax saving instrument while respondents ranked Housing Loan(HL) as III $^{\text {rd }}$. Children Tuition Fees ranked as $\mathrm{IV}^{\text {th }}$ highest preferred tax saving instruments. Fixed Deposit ranked as $\mathrm{V}^{\text {th }}$. Respondents preferred National Pension Scheme as the $\mathrm{VI}^{\text {th }}$ and National Saving Certificates ranked as VII $^{\text {th }}$. Health insurance ranked as VIII ${ }^{\text {th }}$ and Donation ranked as IX ${ }^{\text {th }}$ and Equity Linked Saving Scheme ranked as $\mathrm{X}^{\text {th }}$ respectively.

\section{Conclusion}

This is bases of this study, the respondents rank various tax saving instruments according to their priority of saving tax. The most adopted tax saving 
International Journal of Trend in Scientific Research and Development (IJTSRD) ISSN: 2456-6470

instrument is Provident Fund, which got the first rank in this study. The second most adopted tax saving instrument is Life Insurance Policy. Further, the third choice is Housing Loan Interest and Payment of housing loan, the fourth choice is Children Tuition Fees. After that Fixed Deposit, National Pension Scheme, National Saving certificates, Health Insurance Plans, Donation and Equity Linked Saving Schemes respectively. Any individual who want to assessee income tax and want to do tax planning and savings, first calculate for total income then compute the income tax by deduction and adjustment in total income as per tax table structure. If tax is paid in access then get refund from the income tax department.

\section{REFERENCE}

1. Banks, J., Andrew Dilnot and Sarah Tanner (1997): "Taxing Household Saving: What Role for the New Individual Savings Account?" Commentary No. 66, London: The Institute for Fiscal Studies.

2. Capital Tax Group (1989): "Neutrality in the Taxation of Savings: An Extended Role for PEPs",Commentary No. 17, London: Institute for Fiscal Studies.

3. Chelliah, Raja J. (1996): “An Agenda for Comprehensive Tax Reform" Towards sustainable Growth- Essays in Fiscal and Financial Sector Reforms In India, Oxford University Press, New Delhi.

4. Chelliah, Raja J. and R. Kavita Rao (2001):"Rational Ways of Increasing Tax Revenues in India" presented in World Bank Conference Fiscal Policies to Accelerate Economic Growth, New Delhi, May 21-22.

5. Dr. Ahuja, Girish and Dr. Gupta, Ravi. (2007):"Systematic approach to Income Tax and Central Sales Tax" Book, Bharat Law House Pvt. Ltd.Publication, New Delhi.

6. Lal, B.B and Vashisht, N. (2008): "Direct Taxes, Income Tax, Wealth Tax and Tax planning" Book, Pearson Education, New Delhi.

7. Planning Commission, Government of India (2001):"Report of the Advisory Group on Tax Policy and Tax Administration for the Tenth Plan”, New Delhi.

8. Dornbusch, R., Fischer, S., Startz R. (2004). Macroeconomics 9th Ed. New York: McGrawHill.

9. Avadhesh ojha and Manoj gupta, Direct Taxes Ready Reckoner Book, 20 ${ }^{\text {th }}$ Edition A.Y 2017-18 \&
2018-19, Published by: Dr.Avadhesh ojha for Tax publication, Jodhpur, P. 397- 480\& P 27-60.

10. Savita \& Lokesh Gautam, ( 2013)“'Income Tax Planning: A Study of Tax Saving Instruments", International Journal of Management and Social Sciences Research (IJMSSR) ISSN: 2319-4421, Volume 2, No. 5, May 2013, P.83 -91.

11. Lall,VD, Direct taxes on individual and business income: Economic implications and impact, Economic and Political Weekly Vol 17, No,12,1982.

12. PeterM.Vasanthi \& Kerr A Lan, "The influence of tax mix and tax policy on saving and capital formation in developing economies; A survey." Asia Pacific Development Journal, Vol.8, Number 1.2001. 